
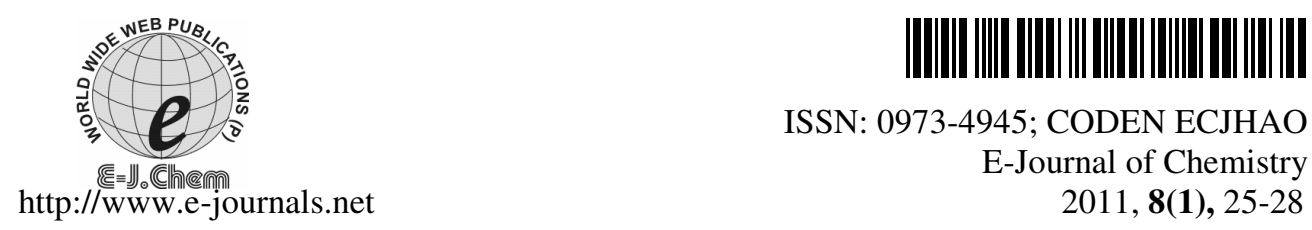

ISSN: 0973-4945; CODEN ECJHAO

E-Journal of Chemistry

2011, 8(1), 25-28

\title{
Nitrogen Mineralization in Soil Amended with Crop Residue: An Incubation Experiment Under Flooding Conditions
}

\author{
K. VIMLESH* and A.K. GIRI \\ Institute of Environment and Development Studies \\ Bundelkhand University, Jhansi, India \\ mahendra_mann1979@rediffmail.com
}

Received 17 July 2009; Accepted 14 September 2009

\begin{abstract}
Incubation studies were carried out to investigate the release of nitrogen in soils. The domestic sewage and soil were analyzed for their physical, chemical characteristics in view of evaluating their suitability for irrigation to agricultural lands in a laboratory experiment. The effluents were added to a soil and incubated at $30 \pm 1{ }^{\circ} \mathrm{C}$ microbial population, $\mathrm{NH}_{4}{ }^{+}-\mathrm{N}$ and $\mathrm{NO}_{3}{ }^{-}-\mathrm{N}$ concentration were determined for $0,15,30,60$ and 90 days. The purpose of this study was to determine nitrogen mineralization of domestic sludge in soils comparing leached and non leached incubation procedures
\end{abstract}

Keywords: Incubation studies, Soil, Crop residue, Mineralization.

\section{Introduction}

Most of the nitrogen in the environment is unavailable for plant uptake. Nitrogen in the plant root zone is either nitrogen gas $\left(\mathrm{N}_{2}\right)$, as a component of the air occupying the soil pore spaces or organic nitrogen present in various forms, including plant and microbial proteins and amino acids, in the soil organic matter. In a process known as nitrogen mineralization, the organic nitrogen contained in soil organic matter is converted in to plant useable inorganic forms (ammonium, $\mathrm{NH}_{4}^{+}$and nitrate, $\mathrm{NO}^{-}$) as a result of the activities of soil microorganisms ${ }^{1}$

The application of domestic sludge to agriculture land is generally the most economic out let for sludge because there is an opportunity to recycle beneficial plant nutrients and organic matter in soils used for crop production. Mineralization of organic nitrogen in domestic sludge is a complex process depends upon on several factors such as soil type rate of waste applied soil $\mathrm{pH}$ and moisture ${ }^{2}$.

\section{Experimental}

\section{Sampling}

The soils used were $0-15 \mathrm{~cm}$ samples selected to include a range of organic carbon, CEC and texture. Root portions removed before the soils were air dried, ground and sieved $(<2 \mathrm{~mm})$ 
and stored at $40{ }^{\circ} \mathrm{C}$ under aerobic conditions. The physicochemical properties of soils and domestic sludge (Table 1) were determined by Bremner standard methods ${ }^{3}$.

Table 1. Some physicochemical properties of soils and domestic sludge

\begin{tabular}{lll}
\hline Characteristics & Soils & Domestic sludge(pea straw) \\
\hline Soil $\mathrm{pH}(1: 2)$ & 7.9 & 6.5 \\
$\mathrm{EC}\left(\mathrm{dsm}^{-1}\right)$ & 0.63 & 3.20 \\
Total organic carbon, \% & 0.48 & 8.80 \\
Total nitrogen, \% & 0.05 & 0.90 \\
$\mathrm{NH}_{4}-\mathrm{N}, \mu \mathrm{g} / \mathrm{g}$ soil & 8.9 & 725.0 \\
$\mathrm{NO}_{3}-\mathrm{N}, \mu \mathrm{g} / \mathrm{g}$ soil & 7.8 & 285.8 \\
Water holding capacity (WHC), \% & $55 \%$ & $\mathrm{NA}$ \\
\hline
\end{tabular}

NA: - Not applicable

\section{Soil equilibration}

Before use each soil was amended with finely powdered pea straw at the rate of $0.1 \%$ carbon adjusted to $60 \%$ water holding capacity and incubated at $30 \pm 1{ }^{\circ} \mathrm{C}$ for $0,15,30,60$ and 90 days to activate microorganisms.

\section{Amendment and incubations}

The soils were incubated at $30 \pm 1{ }^{\circ} \mathrm{C}$ in $500 \mathrm{~mL}$ conical flask and soil moisture was maintained at $60 \%$ water holding capacity through out the incubation period. The soil samples were taken after 0,15 , 30, 60 and 90 days of incubation and analyzed for microbial biomass. The soil $\mathrm{pH}$ was estimated in 1:2 soil in water suspension at room temperature by using a single electrode $\mathrm{pH}$ meter ${ }^{4}$.

\section{Nitrogen mineralization}

$100 \mathrm{~g}$ soil samples were placed in $500 \mathrm{~mL}$ Erlenmeyer flasks. The final moisture content of treated and control soils were adjusted to $60 \%$ water holding capacity in each flasks were stoppered with wax and incubated at $30 \pm 1{ }^{0} \mathrm{C}$ for 90 days the level of $60 \%$ water holding capacity by weekly adjustments for nitrogen mineralization. The oven dried $20 \mathrm{~g}$ moist soils were placed in $500 \mathrm{~mL}$ Erlenmeyer flasks and $200 \mathrm{~mL}$ of $2 \mathrm{M} \mathrm{KCl}$ solution were added to the flasks and placed on a rotatory shaker for 40 minute and the contents filtered through Whatman filter paper no 42. The soil extracts were used for the measurement of $\mathrm{NH}_{4}{ }^{+}-\mathrm{N}$ and $\mathrm{NO}_{3}-\mathrm{N}$ by steam distillation procedure using $\mathrm{MgO}$ and Devarda's alloy ${ }^{5,6}$.

\section{Results and Discussion}

\section{Physicochemical properties of soil and domestic sludge (pea straw)}

Soil and domestic sludge for the incubation studies were analyzed which reveals a pH values at alkaline and acidic range 7.9 and 6.5. Electrical conductances were also studied to be 0.63 $\mathrm{dsm}^{-1}$ and $3.20 \mathrm{dsm}^{-1}$. Total nitrogen and organic carbon was $0.05,0.90$ and $0.48 \%, 8.80 \%$ respectively. Ammonical nitrogen $\left(\mathrm{NH}_{4}{ }^{-} \mathrm{N}\right)$ and nitrate nitrogen $\left(\mathrm{NO}_{3}{ }^{-} \mathrm{N}\right)$ were also analyzed to be $3.8 \mathrm{ppm}, 725.0 \mathrm{ppm}$ and $12.1 \mathrm{ppm} 285.8 \mathrm{ppm}$. These physicochemical properties revealed that the soil to be a fertile one for agriculture (Table 1).

\section{Variation of $\mathrm{pH}$, ammonical nitrogen and nitrate nitrogen during incubation}

The comparison of $\mathrm{pH}$ in the four treatments indicate in flooded waste amended soil is acidic from period of 15-30 days which may be referred due to carbonic acid formation as well as the decomposition product of weak organic acids. After periods of 60 days and 90 days the $\mathrm{pH}$ were maintained at neutral due to biological decarboxylation of organic anions. It was observed that $\mathrm{pH}$ values in flooded waste amended soil increases after 60 days onwards. While other three 
treatments corresponding values on 60 days maintained in acidic $\mathrm{pH}$ which may be referred to more amount of formation of ammonical nitrogen in flooded waste amended soil. Ammonical nitrogen in both waste amended treatments higher values in all periods of incubation (Table 2).It is important to be noted that $\mathrm{NH}_{4}{ }^{+}-\mathrm{N}$ in flooded conditions is highest as dominant anaerobic reducing condition is prevalent ${ }^{6}$. From this investigation of $\mathrm{NH}_{4}{ }^{-}-\mathrm{N}$ it is categorily identified that greater plant available $\mathrm{NH}_{4}{ }^{+}-\mathrm{N}$ is present in flooded waste amended soil than $60 \%$ water holding capacity waste amended soils. Hence flooded conditions may be preferable for better management of crop residue for agricultural productivity so for $\mathrm{NH}_{4}{ }^{+}-\mathrm{N}$ is concerned. The changes in $\mathrm{NO}_{3}{ }^{-} \mathrm{N}$ content in all the treatments are statistically significant on 15 days onwards during the period of incubation. The study reveled that the lowest $\mathrm{NO}_{3}{ }^{-} \mathrm{N}$ were recorded on 90 days in flooded waste amended soil where as in $60 \%$ water holding capacity recorded highest value of $\mathrm{NO}_{3}^{-}-\mathrm{N}$ during incubation. These values are expectedly due to difference in the oxygen availability leading to nitrate formation during decomposition. The nitrate values in all the periods are statistically significant, due to the significant effects of the treatments used during incubation. It is observed that the $\mathrm{NO}_{3}{ }^{-} \mathrm{N}$ are significantly increasing though out the period of incubation at $60 \%$ water holding capacity which may due to aerobic oxidation leading to formation of nitrates in flooded conditions significantly decreases due to reducing conditions ${ }^{\top}$.

Table 2. Effects of soil mineralizable nitrogen during incubation procedure

\begin{tabular}{|c|c|c|c|c|}
\hline \multirow{3}{*}{ Days } & \multicolumn{4}{|c|}{ Treatments } \\
\hline & \multicolumn{2}{|c|}{$60 \%$ moisture contents } & \multicolumn{2}{|c|}{ Flooded conditions } \\
\hline & CS & SCR & $\mathrm{CS}$ & SCR \\
\hline \multicolumn{5}{|l|}{0 Days } \\
\hline $\mathrm{pH}$ & 7.9 & 7.9 & 7.9 & 7.9 \\
\hline $\mathrm{NO}_{3}{ }^{-}-\mathrm{N}$ & 12.1 & 12.1 & 12.1 & 12.1 \\
\hline $\mathrm{NH}_{4}{ }^{+}-\mathrm{N}$ & 3.8 & 3.8 & 3.8 & 3.8 \\
\hline Total Min. $\mathrm{N}_{2}$ & 15.9 & 15.9 & 15.9 & 15.9 \\
\hline \multicolumn{5}{|l|}{15 Days } \\
\hline $\mathrm{pH}$ & 7.3 & 7.6 & 7.5 & 5.3 \\
\hline $\mathrm{NO}_{3}{ }^{-}-\mathrm{N}$ & 28.5 & 95.5 & 1.4 & 2.5 \\
\hline $\mathrm{NH}_{4}^{+}-\mathrm{N}$ & 5.46 & 6.44 & 5.32 & 97.8 \\
\hline Total Min. $\mathrm{N}_{2}$ & 33.96 & 101.94 & 6.72 & 100.3 \\
\hline \multicolumn{5}{|l|}{30 Days } \\
\hline $\mathrm{pH}$ & 7.3 & 7.6 & 7.1 & 5.4 \\
\hline $\mathrm{NO}_{3}{ }^{-} \mathrm{N}$ & 38.5 & 115.5 & 1.2 & 0.8 \\
\hline $\mathrm{NH}_{4}{ }^{+}-\mathrm{N}$ & 5.16 & 18.3 & 8.3 & 127.8 \\
\hline Total Min. $\mathrm{N}_{2}$ & 40.58 & 130.7 & 9.4 & 128.6 \\
\hline \multicolumn{3}{|l|}{60 Days } & 62 & \\
\hline $\mathrm{pH}$ & 0.9 & $\begin{array}{c}6.9 \\
105\end{array}$ & 0.2 & 7.4 \\
\hline $\mathrm{NO}_{3}^{-}-\mathrm{N}$ & 46.7 & 118.5 & 1.2 & 0.6 \\
\hline $\mathrm{NH}_{4}{ }^{+}-\mathrm{N}$ & 7.16 & 21.3 & 10.3 & 130.8 \\
\hline $\begin{array}{l}\text { Total Min. } \mathrm{N}_{2} \\
90 \text { Days }\end{array}$ & 54.12 & 139.3 & 11.4 & 131.6 \\
\hline $\mathrm{pH}$ & 6.9 & 7.1 & 7.3 & 7.0 \\
\hline $\mathrm{NO}_{3}{ }^{-}-\mathrm{N}$ & 49.8 & 125.5 & 0.8 & 0.6 \\
\hline $\mathrm{NH}_{4}^{+}-\mathrm{N}$ & 10.2 & 28.3 & 16.3 & 137.8 \\
\hline Total Min. $\mathrm{N}_{2}$ & 60.58 & 149.7 & 17.4 & 135.6 \\
\hline
\end{tabular}

Note: Control soil (CS), Soil with crop residue (SCR) Total mineralizable nitrogen

(Total Min. $\mathrm{N}_{2}$ ) 


\section{Variation of total mineralizable nitrogen during incubation}

It is revealed from the investigation that total mineralizable nitrogen is increasing in all the treatments during the incubation. This increasing content of mineralizable nitrogen may be referred to active microbial decomposition and accompanied with mineralization of nitrogen. It is noted that both the treatments of soil amended with crop residue significantly improved, in mineralizable nitrogen during incubation suggesting economic value of crop residue for agricultural production. Total mineralizable nitrogen in flooded waste amended soil are reportedly lower in comparison to $60 \%$ water holding capacity, which may be possible due to denitrification of $\mathrm{NO}_{3}-\mathrm{N}$ in flooded conditions ${ }^{8}$.

\section{Conclusions}

Soil samples characterized in our study indicate the soil fertile for crop production. However, less organic carbon content needs crop residue in corporation for improving further its productivity.

\section{References}

1. Jonathan Deenik, Soil and Crop Management, 2006, SCM-15.

2. Brady N C and Well R R C, Pearson Education Incorporation, Delhi, India, 2002.

3. Bremner J M, Inorganic forms of Nitrogen. In Methods of Soil Analysis, Part 2, Ed., Black C A, American Society of Agronomy, Monogr Inc., Madison, 1965, 1179-238.

4. Gurcan Guleryuz, Serap Kirmizi and Hulya Arslan, Turk J Bot., 2007, 31, 277-286.

5. Nourbakhsh F, Plant Soil Environ, 2006, 52(3), 137-140

6. Dar Gh Hassan and Mishra M.M, Environ Pollut, 1993, 84, 285-290.

7. Makeague J.A Manual on Soil Sampling and Methods of Analysis. Subcommittee (of Canada Soil Survey Committee) on methods of analysis 1978, Soil Research Institute, Research Branch Agriculture, Canada, Ottawa, Ontario.

8. Mark Corbeels, Georges Hofman and Oswald Van Cleemput, Plant and Soil, 2000, 218, 71-82. 


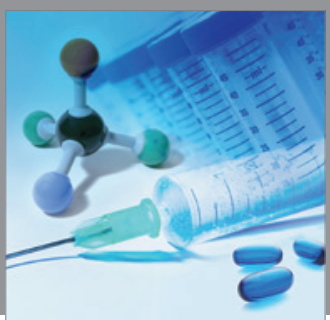

International Journal of

Medicinal Chemistry

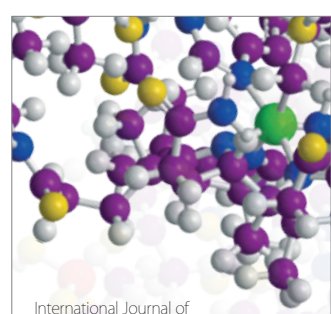

Carbohydrate Chemistry

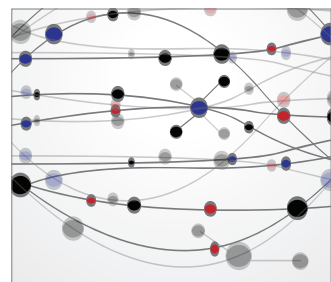

The Scientific World Journal
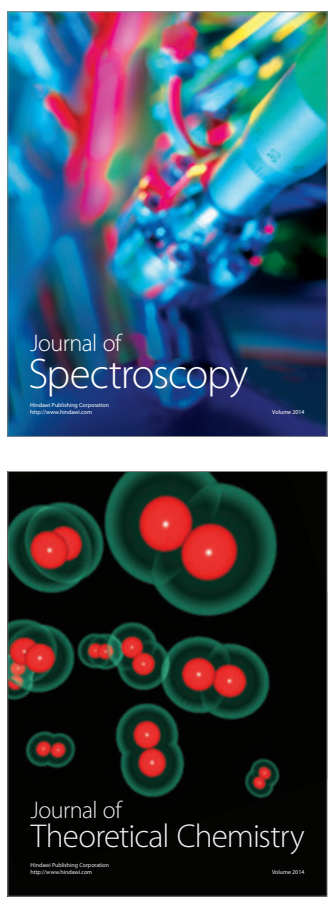
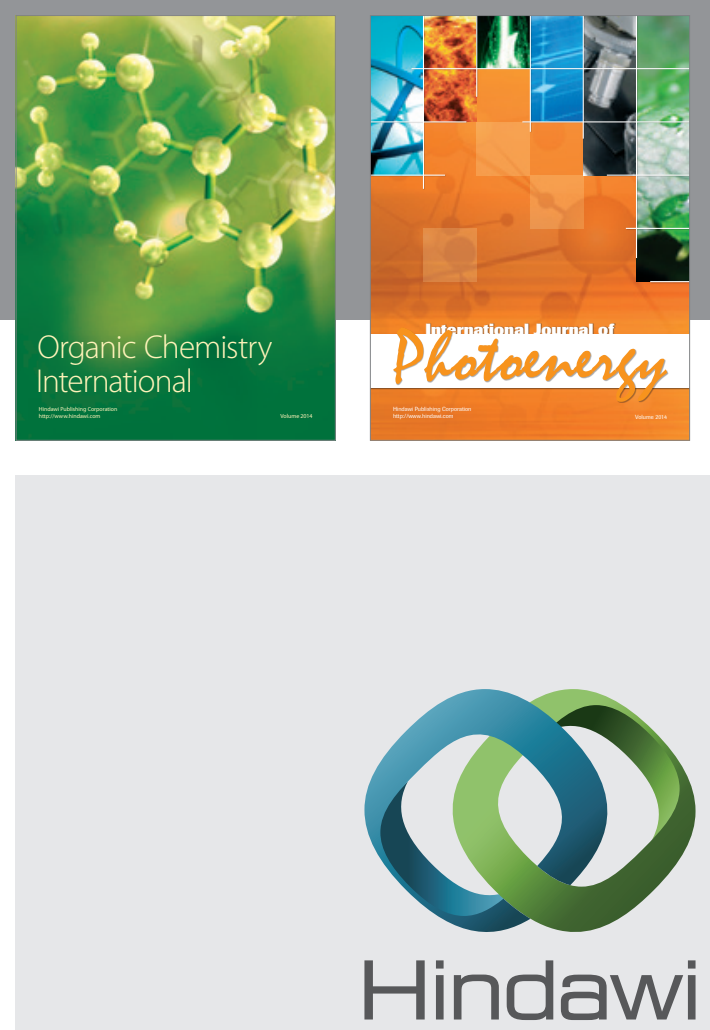

Submit your manuscripts at

http://www.hindawi.com
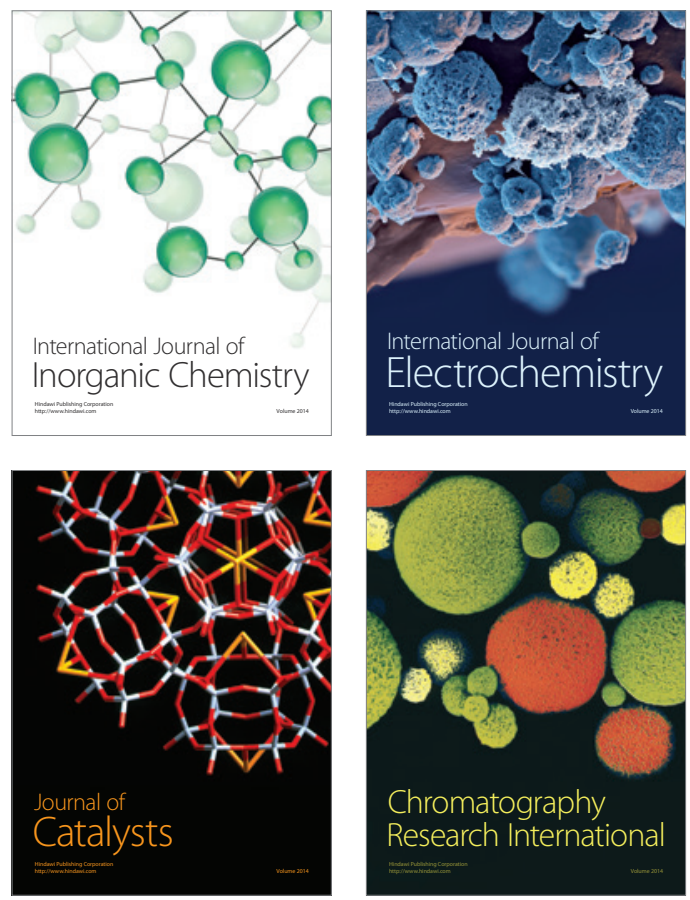
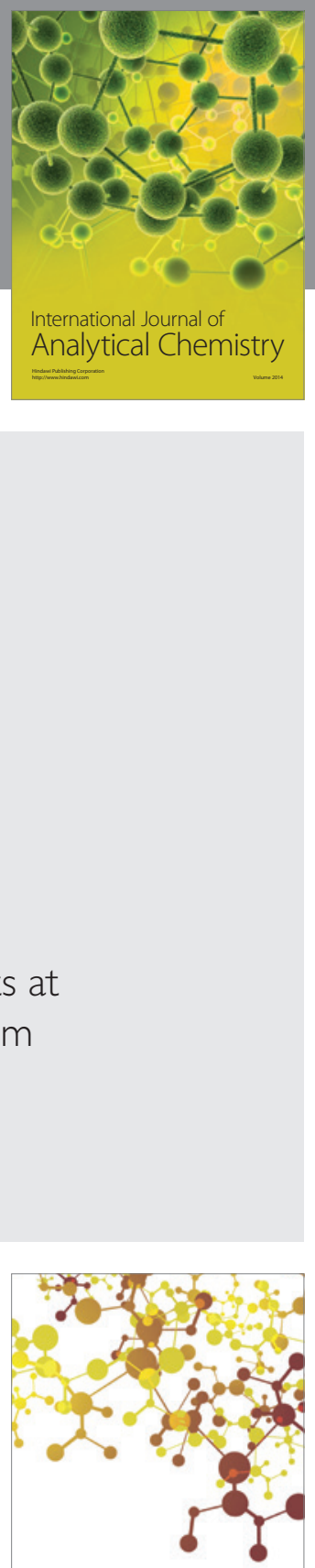

Journal of

Applied Chemistry
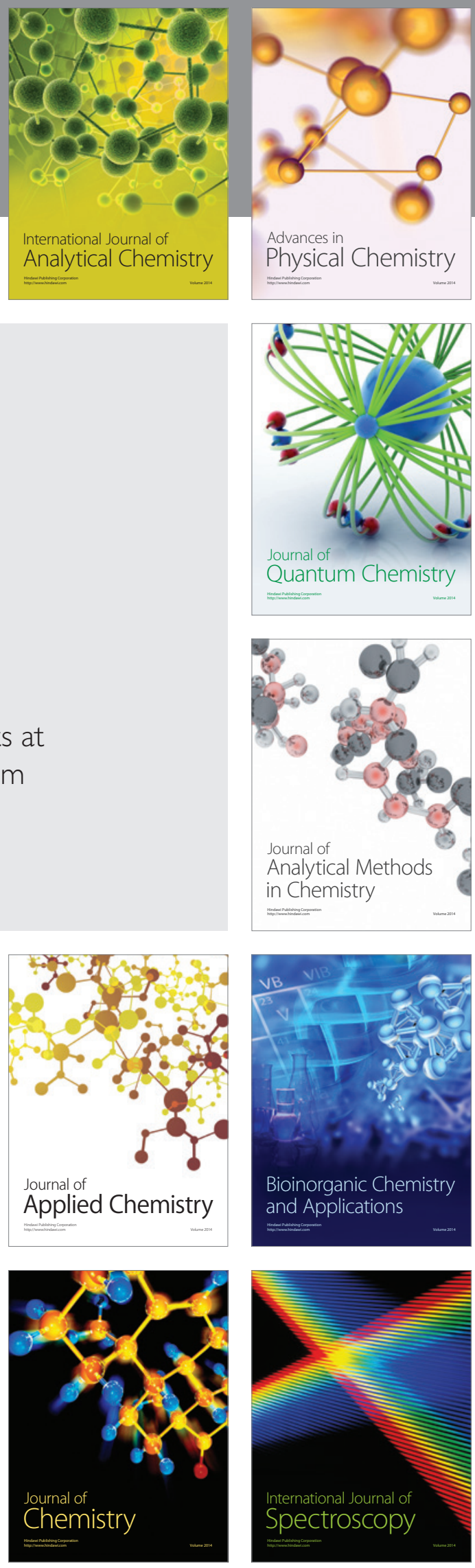